Exploring The Importance Of Internal And External Factors Related To Integrated Marketing Communication In Five Star Hotels Travel Agencies

Maher Fouad Hossny

Faculty of Tourism and Hotel Management, Hotel Management Department

Pharos University in Alexandria

Nehal Mohamed ELtayeb

Faculty of Tourism and Hotel Management,

Tourism Department

Pharos University in Alexandria

\title{
Abstract
}

The importance of integrated marketing communications (IMC) has become a significant example of development in the marketing discipline. IMC is a simple concept that ensures that all forms of communications and messages are carefully linked together. Thus, IMC has two factors that drive or hinder the achievement of certain levels of integration in tourism and hospitality, which also allow dividing them into two large groups: internal and external factors.

This paper examines the internal and external factors of IMC, specifically the success of travel agencies and hotels with the integrated communication strategy because the control of internal and external factors would lead hotels and travel agencies to benefit from using IMC.

The findings of this study show the role of IMC in helping the marketing directors and managers foster the decision marketing process through examining the importance and value of the internal and external factors in a marketplace where IMC is apparently becoming more important for hotels and travel agencies.

Keywords: Integrated marketing, benefits, Communication, internal factors, external factors 


\section{Exploring The Importance Of Internal And External Factors Related To Integrated Marketing Communication In Five Star Hotels Travel Agencies}

\section{INTRODUCTION:}

Integrated Marketing Communication (IMC) acts as a strong tool that leads employees to implement marketing communications more appropriately and effectively (Rehman and Ibrahim, 2011). According to (Shimp 2010),integrated marketing communication represents the planning, creation, integration and implementation of communication channels which a consumer has with a certain brand, and alsoinfluence his purchase decision. The fast growth of the Internet and WWW has great impacts on the industry that may influence consumer-purchasing decisions (Sotiriadis and van Zyl, 2013).

Saeed et al. (2013) pointedout that IMC marketers should concentrate on customer's preferences, purchase patterns, media and social networks, and other elements so that consumers are exposed to products that adequately meet their needs through communication mix tools, and whichthe consumer would find more attractive and credible. IMC is used to coordinate all communication tools in every customer touch point towards the direction of a single specific goal. This concept shows that brand personality, messages and position are derived from a unique strategy, and are delivered to the customer in collaboration with all other communication elements. (Ekhlassi2012). Therefore, the role of IMC and the need of functional relation interaction among companies, customers, and other stakeholders are of great significance (Duncan2002).

Marketing communications represent gathering of all components in a brand's marketing mix that promote exchanges by building shared meanings with the stakeholders of brand. The main goals of the marketing communication are to provide information to customers and to increase the sales (Saeed et al. 2013). Marketing communication is the collective term for all the communication functions used in marketing a product (Duncan 2002). Smith, et al. (2006) statedthat the greater utilization of marketing communication tools within an IMC approach, the better overall outcome and a complete image may be delivered as well.

Although IMC has been successfully implemented by many manufacturing and service businesses, it is still relatively not implemented properly in the hotels and travel agencies in Egypt. Therefore, the main purpose of this study is to determine the importance of internal and external factors for hotels and travel agencies to improve the integrated marketing communication strategy. 


\section{LITERATURE REVIEW The concept of IMC}

IMC has become well known internationally during the 1990s. Thus IMC is a term that is recently used; a fact, which might explain why there may not yet be a common understanding of its real meaning and a lack of a generally accepted definition (Kotler 2003). Schults et al. (1992) describedthe term integration as a reflection in increasing the number of marketing communication firms willing to achieve integration within their own organizations.

IMC provides information and influences visitors' behavior, where customers receive messages of all sorts of information (Wang et al. 2009). Grewal and levy (2011) described IMC as the representation of the Promotion $\mathrm{P}$ of the four Ps. It comprises a variety of communication tools such as advertising, personal selling, sales promotion, public relations, direct marketing, and online marketing including social media in combination to provide lucidity, coherence, and maximum communicative impact.

Hudson \& Hudson (2010) advised that the travel agencies and hotels have to promote their products in order to encourage the customers to purchase it. This is described as the pull strategy which emphasize on spending a huge amount of money on advertising and consumer promotion to increase consumer demand; if successful, consumers will ask their retailers for the product, the retailers will ask the wholesalers, and the wholesalers will ask the producers. In order to reach a better understanding of the full meaning and process of IMC (Smith et al. 1999) have developed a tool, which is supposed to show marketing integration as occurring on one or more of seven levels. They distinguish the following levels and corresponding degrees of integration:

1. Vertical objectives integration. It means that communication objectives fit with marketing objectives and the overall corporate objectives.

2. Horizontal/functional integration which means that marketing communications activities fit well with other business functions of manufacturing, operations and human resource management.

3. Marketing mix integration: The marketing mix of product, price and place decisions is consistent with the promotion decisions, e.g. with the required communication messages.

4. Communications mix integration: All the 12 communications tools are being used to guide the customer/consumer/client through each 


\section{Exploring The Importance Of Internal And External Factors Related To \\ Integrated Marketing Communication In Five Star Hotels Travel \\ Agencies}

5. stage of the buying process and all of them portray a consistent message.

6. Creative design integration: The creative design and exclusive is uniform which is consistent with the chosen positioning of the product.

7. Internal/external integration: All internal departments and all external employed agencies work together to an agreed plan and strategy.

8. Financial integration: The budget is being used in the most effective and efficient way ensuring that economies of scale are achieved and that long-term investment is optimized.

\section{Definitions of Integrated Marketing Communication}

Schultz and Kitchen (1997) defined IMC as a concept of marketing communications planning that realizes the added value of an inclusive plan that evaluates the strategic roles of a variety of communication tools (for example, general advertising, direct response, sales promotion, and public relations) and combines these tool to provide clarity, consistency, and maximum communications impact. (Kotler et al. 1999) adds that corporate learning in the definition according to his point of view; companies should plan at corporate function level as well as at communication level. (Schultz and Schultz 2004) defined IMC as a strategic business operation used to plan, develop, execute, and evaluate coordinated, measurable, persuasive brand communication programs over time with consumers, customers, prospects, and other targeted, relevant external and internal audiences. IMC is also defined by Duncan (2002) as a process, that includes varied company function, while it monitors and affects the messages (produced by the company) on a strategic level. In addition, it encourages two-way, data-based dialogues so as to build up and boost a profitable relationship with consumers or other stakeholders.

\section{Necessary conditions for IMC success:}

Pettegrew (2001) proposedthat there must be a series of important conditions that must exist in IMC. Those conditions have to be fostered by a company. Based on these conditions, six recommendations for best implementations of IMC are offered:

- IMC must be implemented systemically and simultaneously on all levels and functions of a company. The integration of public relations and marketing functions does not qualify the company as an IMC exemplar.

- The Chef Executive Officer must support directly IMC 
implementation because without his final decision, IMC efforts are

- subject to failure

- Giving an insight for companies with strong marketing cultures because issues like corporate reputation would take a back seat to the provincialism of brand management.

- Functional and structural issues must become essential components of any effective IMC program.

- Any IMC program must be adapted according to the unique character of a particular organizational culture: A "one-size-fits-all"

- There is no program of IMC, but to make it work effectively itmust reflect the culture that it operates in.

- Companies must look for IMC small successes in traditional businesses for example.

\section{Internal Factors of IMC:}

\section{1- TOP management :}

Top management commitment is one of the aspects that have a great influence on the management of IMC in the business process. Top management commitment shows that senior managers emphasize on coherence between what they are willing to say and do, which could prevent middle managers from having any confusion that can damage desired integration. The lack of commitment with integrated communication at senior management level usually leads to organization structure separation in communication tools and with communication managers (Smith 1996 and Einwiller 2011).

Top management attitude for change positively influences IMC; for top management must be willing to change the policies that would disturb the implementation of IMC (Phelps et al. 1996). Risk tolerance is also a related factor that influences IMC implementation. The fitting of risk tolerance requires top management to suppose the ingrained risk in controlling dynamic changing markets (Phelps et al. 1996).

The internal factors should be related to structural issue and top management; the responsibility of managing messages should be located at the highest level of the organization structure "Top management" (Schultz 1996). Schultz and Kitchen (2000) corroborate that communication management system is based on centralization, control, which make upthe setting in addition to keeping the customer well oriented. 


\section{Exploring The Importance Of Internal And External Factors Related To Integrated Marketing Communication In Five Star Hotels Travel Agencies}

\section{2- Interdepartmental dynamic:}

Market and brand orientation: some studies have shown that market and brand orientation positively influence implementation of IMC programs. Each factor of these affects the others alternately (Reid 2005). Professional training, expertiseare required for the manager of client business cannot find well-trained and expert staff for implementing IMC Programs. (Bread 1996)

\section{3- Cross functional management:}

The obstacles take place in creating cross-functional teams that operate at the brand equity level. The marketing and Human Resources departments should work together, for instance: "strong corporate equity with brand customers can improve the return for HR, while at the same time improved HR can improve the return on brand equity from external customers." This can only happen if the departments removes the barriers between them .(Ambler and barrow 1996 )

\section{4- Internal conflicts and lack of horizontal communication}

Without cross-internal communication, departments can face difficulties in sharing and exchanging essential information about their customers. Developed horizontal communication and fare competition can expand the amount of customer's choice in a capitalist context (Kim et al. 2004)

\section{5- Cross functional coordination:}

Horizontal processes are important to override the obstacles of specialization and organizational structure which leads employees from different departments to ommit to their activities. (Schultz and kitchen 2000)

\section{6- Organizational systems and structures :}

According to (Lucia et al. 2012) Brand responsibility and marketing communication don't have to be centralized in a unique location but the communication program should be in a centralized location to assure the consistency of messages and avert any dispersion relating to communication resources . (Duncan and Everett 1993) assumed that IMC is a mechanism used by consumers and stakeholders to create a consistency and a unique image of the organization. Central control of messages may lead to consumers' dissatisfaction if they do not receive any reply for their needs (Lucia et al. 2012). Beard (1996) indicatedthat rigid organization structures represent an obstacle in implementing IMC. Companies can get over these internal obstacles by a collective agreement about the approach they apply (Schultz et al. 1993) 
A good leader can better his employees; he/she knows how to authorize his/her employees and encourage teamwork. Senior managers sometimes resort to the principles of leadership under pressure in times when they are in need of quick decisions. Many managers ignore the consensus model and

follow a "heroic" model; they prefer to implement their own decision regardless of the team's decision (Joseph et al. 1996).

Organizational sizecan have an impact on the ability to implement IMC (Low 2000). Further studies added that the larger the organization is the lower it is to implement IMC (Cornelissen et al. 2001).

\section{External Factors of IMC:}

External Factors are described by Schultz (1996) as the essential elements that affect integrating approach are the technological developments as they integrate communication and distribution in addition to making the world more connected. Johnson and Scholes (2002) claim that that strategy can be seen as the matching or the resources and activities, or as an organization to the environment in which it operates, which is sometimes known as the search for strategic fit. Besides identifying strengths and weaknesses, threats and opportunities in the business environment it is important to achieve the correct positioning of the company including the organization of the three concepts: identity, profile and image. Questions concerning the connection between these concepts are of the utmost importance for the organization's relations to its marketits ability to develop, maintain and increase a competitive position (Holm 1998).

\section{Benefits of IMC:}

Advertising, sales promotion, direct marketing and public effectiveness are all higher when hotels/ travel agencies implement a higher level of IMC (Low 2000). IMC produces benefits in the implementation of marketing campaigns, which influences customer attitude, loyalty and retention (Beard, 1996). According to (Lucia et al. 2012) IMC submits savings and costs relevant to the organization facilities. Collaboration within departments evades unnecessary communication duplication and shows an enhancement in operational and message consistency. In addition, (Duncan 1997) statedthat IMC implementation in hotels and travel agencies would achieve higher income in each campaign as a result of the integration of all the tools of communication mix.

Achievement of competitive advantage is one of the benefits of IMC in the market because it allows "better brand reputation and knowledge and enhancement of the attitude to the brand.Moreover, itencourages the purchase and intention toward the brand" (Swain 2004). Marketing strategy 


\section{Exploring The Importance Of Internal And External Factors Related To Integrated Marketing Communication In Five Star Hotels Travel Agencies}

implementation has an impact on customer's loyalty, retention and attitude (Rust et al. 2004). Others indicated that the benefits of integrated marketing communication in hotels and travel agencies will be as the following:

\section{1- Create competitive advantage :}

The IMC improves communication quality of a company and help them to think differently in a way that focuses on managing customer relationships.Furthermore, organizations build relationships with customers, which could be seen as a competitive advantage (Gato 2011)

\section{2- Boost sales and profits}

By using IMC, a coherent set of messages is delivered to all target audiences by all available forms of contact and message channels. Consequently, effectively implemented IMC strategy can increase marketing sales and reduce costs depending on the change in customers' behavior (Wang et al. 2009).Reid, 2005 also addedthat stronger customer relationsand the financial returns from such relationships, have great impacts on market position and financial position. The consumer would have more awareness and would be able to make the purchase decision (Lee 2004).

3- Save time money and stress

Using IMC saves time and money, and improves the travel agencies' and hotels' ability to protect the integrity of the service. It can also maximize the financial returns and minimize selling stress (Lee 2004)

\section{4- Build clear brand image}

Ghodeswar (2008) statedthat the different sources and levels of knowledge such as awareness, attributes, benefits, images, thoughts, feelings, attitudes, and experiences get linked to a brand andit is understood by the consumer. That would lead to a long term security and build a long relationship with the customer in addition to higher sustainable profits and these long term relations are more effective than the traditional marketing tools .

\section{5- Achieve synergy :}

Kerr and Patti (2002) statedthat a real benefit of IMC lies in the stronger internal coordination of the marketing communication disciplines and the aim for shared objectives and greater accountability. All communications must have one voice to achieve a strong and brand image, otherwise it can result in providing different and confusing messages to the consumer (Ejebro 2007 ). 


\section{Methods}

This study is conducted with 147 senior sales and marketing managers from five-star hotels and travel agencies category " $\mathrm{A}$ " who agreed to participate. There were 77 sales and marketing managers from five-star hotels and 70 sales and marketing managers from travel agencies.

The data were collected using a convenient sampling technique. The questionnaire was sent both via email to all the senior managers and through personal interview by the researchers. Using online survey methods for the research is due to a number of reasons. First of all, the researcher assumed that managers were available via email and accordingly, the problem of validity was solved. Secondly, the costs were decreased by not having to print the questionnaires.Thirdly, it is believed that online surveys are more comfortable to managers who carry out their everyday tasks on their computer.

A structured questionnaire, composed of 20 close-ended questions, has been developed based on prior studies (Kitchen et al. 2010; Holm 2006; Smith et al. 1999). The questionnaire includes five sections and each part was measured by three to six measurement items, which were adopted from (Smith et al. 1999). The five measured constructs include Top Management Commitment (4 items), Interdepartmental Dynamic (6 items), Organizational Systems and Structures (4 items), External Factors (3 items), Hotels and travel Agencies Benefits from IMC Implementation (3 items).

All items employed a five point Likert-type scale with one being "strongly disagree" and 5 being "strongly agree". After the formation of the questionnaire, a small number of experts (mainly academics and hotel managers) were asked for their opinions on suitability of the questions. Respondents did not have any difficulty in understanding the questions, indicating the sheer validity of the questionnaire.(Judd,et al. 1991). To aid in the interpretation of these scales, the researchers have established an interpretive scale for the results as follows: " 4.5 or greater = Strongly Agree; $4.49-3.50=$ Agree; $3.49-2.51=$ Neither Agree nor Disagree; $2.5-1.51=$ Disagree; and 1.50 or less = Strongly Disagree".

The target population of this study consists of all sales and marketing directors and managers of the five star hotels and travel agencies in Cairo and Alexandria. The self-administered questionnaire targets hotel and travel agencies, as most of the time they are involved in developing the sales and marketing process. 


\section{Exploring The Importance Of Internal And External Factors Related To Integrated Marketing Communication In Five Star Hotels Travel Agencies}

The goals of the present study are as follows:

1. To deepen understanding the importance and value of internal and external factors in a marketplace where IMC is apparently becoming more important for hotels and travel agencies

2. To examine the benefits of implementing the IMC in hotels and companies of travel agencies.

\section{Findings and Discussion}

Descriptive analyses have been carried out by using Statistical Package for the Social Sciences (SPSS) for Windows version 17.0. Simple frequency distributions have been computed for each of the questions. A fivepoint Likert scale ranging from $1=$ strongly disagree to $5=$ strongly agree was used in questionnaires. The mean scales for the internal and external factors is shown in table 1

\section{Table 1}

Scale item, Mean and standard deviation for Internal and external factors of integrated marketing communication

\begin{tabular}{|l|c|c|c|c|}
\hline \multicolumn{1}{|c|}{ Scale items } & \multicolumn{2}{c|}{ Hotels } & \multicolumn{2}{c|}{$\begin{array}{c}\text { Travel } \\
\text { Agencies }\end{array}$} \\
\cline { 2 - 5 } 1- INTERNAL FACTORS & Mean & $\begin{array}{c}\text { Std. } \\
\text { Dev. }\end{array}$ & Mean & $\begin{array}{c}\text { Std. } \\
\text { Dev. }\end{array}$ \\
\hline \multicolumn{1}{|c|}{ Top Management Commitment } & & & & \\
\hline $\begin{array}{l}\text { Top management commitment implies that senior } \\
\text { managers ensure coherence between what they say } \\
\text { and what they do in order to prevent middle } \\
\text { managers from perceiving ambiguity that can } \\
\text { damage the desired integration }\end{array}$ & 4.08 & 1.21 & 3.78 & 1.11 \\
\hline $\begin{array}{l}\text { top management attitude towards change positively } \\
\text { influences IMC: top management must have the } \\
\text { will to change corporate policies that hinder IMC } \\
\text { implementation }\end{array}$ & 4.05 & 1.22 & 3.85 & 1.01 \\
\hline $\begin{array}{l}\text { The risk of Top management tolerance positively } \\
\text { influences the implementation of IMC programs }\end{array}$ & 3.34 & 1.44 & 3.46 & 1.26 \\
\hline $\begin{array}{l}\text { The system of communication management, based } \\
\text { on centralization and control, allows setting and } \\
\text { keeping a customer-based orientation }\end{array}$ & 4.28 & 1.03 & 3.83 & 1.14 \\
\hline \multicolumn{1}{|c|}{ Overall } & $\mathbf{3 . 9 3}$ & $\mathbf{0 . 4 1 1}$ & $\mathbf{3 . 7 3}$ & $\mathbf{0 . 1 8 2}$ \\
\hline interdepartmental dynamic & & & & \\
\hline $\begin{array}{l}\text { Market orientation positively influences } \\
\text { implementation of IMC programs }\end{array}$ & 2.91 & 1.33 & 4.14 & 0.67 \\
\hline $\begin{array}{l}\text { Brand orientation positively influences } \\
\text { implementation of IMC programs }\end{array}$ & 3.62 & 1.33 & 4.11 & 0.98 \\
\hline Professional training and expertise in cross- & 3.62 & 1.51 & 3.94 & 1.04 \\
\hline
\end{tabular}




\begin{tabular}{|c|c|c|c|c|}
\hline $\begin{array}{l}\text { functional management positively influences } \\
\text { implementation of IMC programs. }\end{array}$ & & & & \\
\hline $\begin{array}{l}\text { Horizontal communication positively influences } \\
\text { implementation of IMC program }\end{array}$ & 3.86 & 1.31 & 4.16 & 0.80 \\
\hline \begin{tabular}{lclc} 
Internal & conflicts & and & \multicolumn{2}{c}{ departmentalization } \\
negatively & influence & implementation of IMC \\
programs & & &
\end{tabular} & 3.44 & 1.37 & 3.88 & 1.11 \\
\hline $\begin{array}{l}\text { The hierarchy of our organizational plan include } \\
\text { the position of Director of sales and marketing and } \\
\text { he is the person who is responsible for the IMC } \\
\text { process }\end{array}$ & 4.20 & 1.06 & 3.90 & 0.84 \\
\hline Overall & 3.60 & 0.431 & 4.02 & 0.128 \\
\hline \multicolumn{5}{|l|}{$\begin{array}{l}\text { organizational systems and structures influence } \\
\text { IMC implementation }\end{array}$} \\
\hline $\begin{array}{l}\text { The division of the organization into a large } \\
\text { number of departments negatively influences } \\
\text { implementation of integration programs. }\end{array}$ & 3.90 & 1.18 & 3.91 & 0.83 \\
\hline $\begin{array}{l}\text { IMC as a mechanism to control messages whihe } \\
\text { customers and stakeholders use to form a unique } \\
\text { and coherent image about the organization }\end{array}$ & 3.66 & 1.30 & 3.99 & .076 \\
\hline $\begin{array}{l}\text { Organization size positively influences } \\
\text { implementation of integration programs. }\end{array}$ & 4.16 & 1.27 & 3.77 & 1.06 \\
\hline $\begin{array}{l}\text { A leadership position of the organization in the } \\
\text { marketplace positively influences implementation } \\
\text { of IMC programs. }\end{array}$ & 3.83 & 1.55 & 3.96 & 0.79 \\
\hline Overall & 3.88 & 0.207 & 3.90 & $\mathbf{0 . 0 9 7}$ \\
\hline \multicolumn{5}{|l|}{ 2- EXTERNAL FACTORS } \\
\hline $\begin{array}{l}\text { IMC affected by Political factors instability include } \\
\text { laws, agencies and hotel groups that influence and } \\
\text { limit tourism and hospitality companies }\end{array}$ & 4.72 & 0.94 & 4.16 & 1.27 \\
\hline $\begin{array}{l}\text { IMC affected by Instability of Economic factors } \\
\text { include factors that affect clients purchasing power } \\
\text { and spending patterns }\end{array}$ & 4.03 & 1.00 & 3.83 & 1.55 \\
\hline $\begin{array}{l}\text { IMC affected by Technological developments } \\
\text { which have made international travel and } \\
\text { communication more accessible to consumers and } \\
\text { led to a situation in which social habits and } \\
\text { fashions change faster. }\end{array}$ & 3.83 & 1.17 & 2.66 & 1.87 \\
\hline Overall & 4.193 & 0.466 & 3.55 & $\mathbf{0 . 7 8 8}$ \\
\hline $\begin{array}{c}\text { 3- BENEFITS FROM IMC } \\
\text { IMPLEMENTATION }\end{array}$ & & & & \\
\hline $\begin{array}{l}\text { The level of implementation of IMC positively } \\
\text { influences customer attitudes, } \\
\text { loyalty, customer retention }\end{array}$ & 3.83 & 1.55 & 3.79 & 0.84 \\
\hline $\begin{array}{l}\text { IMC provides important savings in additional costs } \\
\text { relating to the organizational facilities. Cooperation } \\
\text { among departments avoids unnecessary duplication } \\
\text { of communication strategies and implies an }\end{array}$ & 3.81 & 0.91 & 3.51 & 1.00 \\
\hline
\end{tabular}




\section{Exploring The Importance Of Internal And External Factors Related To Integrated Marketing Communication In Five Star Hotels Travel Agencies}

\begin{tabular}{|l|c|c|c|c|}
\hline $\begin{array}{l}\text { improvement in operational efficiency and in } \\
\text { message coherence }\end{array}$ & & & & \\
\hline $\begin{array}{l}\text { Marketing communication outcomes positively } \\
\text { influence financial results }\end{array}$ & 3.57 & 0.93 & 3.32 & 0.92 \\
\hline \multicolumn{1}{|c|}{ Overall } & $\mathbf{3 . 7 3}$ & $\mathbf{0 . 1 4 4}$ & $\mathbf{3 . 5 4}$ & $\mathbf{0 . 2 3 6}$ \\
\hline
\end{tabular}

The pervious table shows the analysis of integrated marketing communication as the following:-

\section{1- Internal factors related to IMC:-}

- Top Management Commitment (4 items):-

Hotels and travel agencies Respondents "Agreed (item scores between 4.49 and 3.50) with three of the items Included in the scale except the item "Top management's risk tolerance" which positively influences the implementation of IMC programs" (mean = 3.34, 3.46). Respondents have indicated that they "neither agreed nor disagreed" (item scores between 2.52 and 3.49).

\section{- Interdepartmental dynamic}

Travel agencies Respondents "Agreed (item scores between 4.49 and 3.50) with six of the items included on the scale. However Hotel Respondents have "agreed (item scores between 4.49 and 3.50) with four of the items included on the scale except the item "Market orientation positively influences implementation of IMC programs" (mean = 2.91) and "Internal conflicts and departmentalization negatively influence implementation of IMC programs" (Mean =3.44). Respondents in the previous 2 items have indicated that they "neither agree nor disagree" (item scores between 2.52 and 3.49).

- Organizational systems and structures influence IMC implementation

Hotels and travel agencies Respondents have "Agreed (item scores between 4.49 and 3.50) with all four of the items included on the scale

\section{2- External Factors}

Travel agencies Respondents have "Agreed (item scores between 4.49 and 3.50) with two of the items included on the scale. Except the item "IMC affected with Technological developments which have made international travel and communication more accessible to consumers and led to a situation in which social habits and fashions change more quickly (mean =2.66). Respondents have indicated that they "neither agree nor disagree" (item scores between 2.52 and 3.49). However Hotel Respondents have "Agreed (item scores between 4.49 and 3.50) with two of the items included on the scale except the item "IMC affected with Political factors instability include laws, agencies and hotel groups that influence and limit tourism and 
hospitality companies" (mean $=4.72)$ Respondents have indicated that they "strongly agree" (item scores 4.5 or greater).

\section{3- Benefits from IMC implementation}

Hotels and travel agencies Respondents have "Agreed (item scores between 4.49 and 3.50) with all three of the items included on the scale except the

item "Marketing communication outcomes positively influence financial results" (mean $=3.32$ ) in travel agencies. Respondents indicated that they "neither agree nor disagree" (item scores between 2.52 and 3.49).

Also Table 1 indicates that the results of the Mean scores of each item on the whole mean scores of each item for hotels were slightly higher than those for travel agencies, except for interdepartmental dynamic (Hotels: $\mathrm{M}$ 3.6; SD 0.431/ Travel Agencies: $M$ 4.02; SD 0.128) and organizational systems and structures (Hotels: M 3.88; SD 0.207/ Travel Agencies: M 3.90; SD 0.097). The items under these variables represent a negative attitude towards integrated marketing communication and those two factors in hotels that are likely to be less influential in the degree of integration. On the contrary, the achievement of the desired degree of integration will produce a number of effects on the effectiveness of marketing communication efforts, on brand responsibility, marketing communication, Qualification/training, experience and abilities. Also the lack of horizontal communication was expected to be low in the organizations that do not encourage the concept of integrated marketing communication.

In order to get a clearer picture of mean differences, composite scores for each variable have been calculated by averaging scores representing that variable. Then, an independent sample t-test was carried out to confirm the significance of the differences in mean scores between hotels and travel agencies. Detailed analysis of these differences can be found in table 2. In addition, gap of the mean scores between hotels and travel agencies, are calculated and listed in Table 2.

95\% confidence interval of this difference

$1=$ strongly disagree, $5=$ strongly agree.

Gap $=$ Hotels mean score - Travel agencies mean score,

$\mathrm{SD}=$ standard deviation. $\quad * * \mathrm{p}<.01$ level 


\section{Exploring The Importance Of Internal And External Factors Related To Integrated Marketing Communication In Five Star Hotels Travel Agencies}

\section{Table 2}

Integrated marketing communication Related internal and external factors:

Hotels and travel agencies

\begin{tabular}{|r|c|c|c|c|c|c|c|c|c|}
\hline Variables & \multicolumn{2}{|c|}{ Hotels } & \multicolumn{2}{|c|}{$\begin{array}{c}\text { Travel } \\
\text { Agencies }\end{array}$} & Gap & \multicolumn{2}{|c|}{ T } & SED & Sig. \\
\hline & Mean & $\begin{array}{c}\text { Std. } \\
\text { Dev. }\end{array}$ & Mean & $\begin{array}{c}\text { Std. } \\
\text { Dev. }\end{array}$ & \multicolumn{2}{|c|}{} \\
\hline $\begin{array}{r}\text { Top Management } \\
\text { Commitment }\end{array}$ & 3.93 & 0.411 & 3.73 & 0.182 & 0.2 & 5.3947 & 0.037 & $0.0001^{* *}$ \\
\hline $\begin{array}{r}\text { Interdepartmental } \\
\text { Dynamic }\end{array}$ & 3.60 & 0.431 & 4.02 & 0.128 & -0.42 & 11.3260 & 0.037 & $0.0001^{* *}$ \\
\hline $\begin{array}{r}\text { Organizational } \\
\text { Systems and } \\
\text { Structures }\end{array}$ & 3.88 & 0.207 & 3.90 & 0.097 & -0.02 & 1.0607 & 0.019 & 0.2897 \\
\hline $\begin{array}{r}\text { External Factors } \\
\text { Agtels and Travel } \\
\text { Agencies Benefits } \\
\text { from IMC } \\
\text { Implementation }\end{array}$ & 3.193 & 0.466 & 3.55 & 0.788 & 0.643 & 8.5157 & 0.076 & $0.0001^{* *}$ \\
\hline
\end{tabular}

The largest gap score is found to be in organizational systems and structures, (-0.02), indicating that marketing managers in travel agencies have strong brand responsibility and marketing communication towards the IMC. This gap has considered IMC in travel agencies as a method to control messages that customers and stakeholders use to form a unique and good image about the organization. On the other hand this control of messages in hotels may lead frustration when guests require responses for their special needs or extraordinary circumstances. On the other hand, the lowest gap score calculated belongs to the Hotels and travel agencies benefits from IMC implementation variable with (0.19). This finding indicates that marketing managers in both locations have similar focus and commitment to all aspects that influence the management of IMC as a business process and operational perspective the most. In addition, we could conclude that IMC is likely to produce benefits in the coordination of marketing communication activities and in the coordination of the different functions involved in the implementation of the marketing plan.

The Top management commitment variable implies that senior managers ensure coherence between what they say and what they do in order to prevent middle managers from perceiving ambiguity that can damage the desired integration. 
To assess the equality of variances for all variables calculated for hotels and travel agencies, Levene's test was used to test the null hypothesis that the population variances are equal (called homogeneity of variance or homoscedasticity). The results of Levene's test are shown in table 3

\section{Table 3}

Levene's Test

\begin{tabular}{|l|l|l|l|}
\hline \multicolumn{2}{|l|}{} & $\begin{array}{l}\text { Levene's Test for Equality of } \\
\text { Variances }\end{array}$ \\
\cline { 3 - 4 } \cline { 3 - 3 } & & F & Sig. \\
\cline { 3 - 4 } & & \\
\hline \multirow{2}{*}{ SAMPLE } & Equal variances assumed & .364 & .550 \\
\cline { 2 - 4 } & Equal variances not assumed & & \\
\hline
\end{tabular}

According to the results of Levene's test for the equality of variances, which is used for deciding the case that researcher, will depend on its results, it is noticed that sig (P.Value) is more than 0.05 . Thus, researchers would accept the hypothesis that the equal variance assumed, consequently the researchers can depend on the results of $T$ test for two independent samples (hotels and travel agencies) in the case of assuming equal variances. This concurs with Levene, Howard (1960), who stated that if the result of P-value of Levene's test is less than some significance level (typically 0.05), the obtained differences in sample variances are unlikely to have occurred based on random sampling from a population with equal variances. Thus, the null hypothesis of equal variances is rejected and it is concluded that there is a difference between the variances in the population.

Multiple regression analysis has been carried out by taking the Effects of external factors on IMC with the rest dependent variables and the benefits from IMC implementation as the independent variables; with the rest of the dependent variables. 


\section{Exploring The Importance Of Internal And External Factors Related To Integrated Marketing Communication In Five Star Hotels Travel Agencies}

Table 4

Regression analysis results (Hotels)

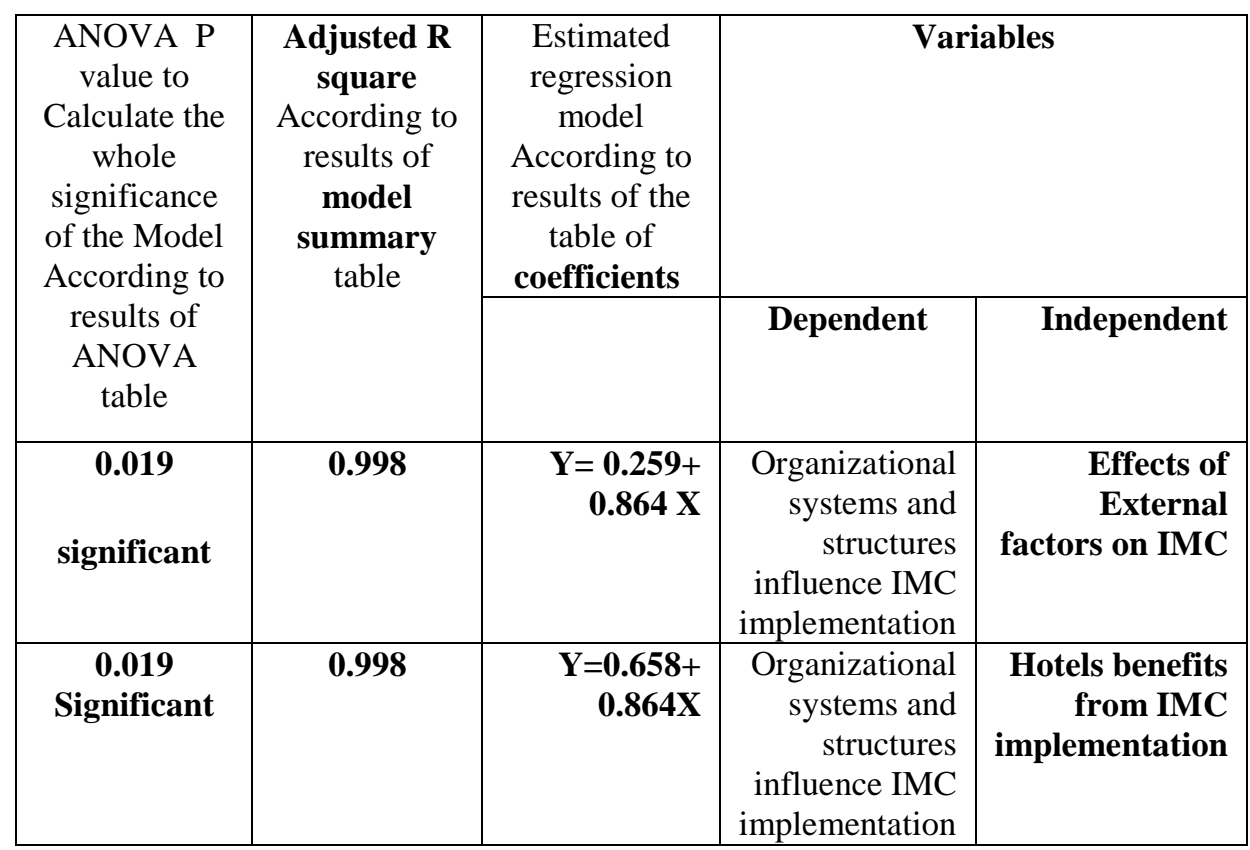

The results of multiple regression analysis for hotels shown in Table 4 demonstrate that the adjusted $\mathrm{R}$ square significant only with The independent variable (Effects of external factors of hotels on IMC) explains that $99.8 \%$ of the variations in the dependent variable (Organizational systems and structures influence IMC implementation), And the other variations occur due to other factors as well as the random error. Thus this result indicates that the External factors of IMC positively influence the Organizational system structure"

In addition, the independent variable (Hotels benefits from IMC implementation) explains that $99.8 \%$ of the variations in the dependent variable (Organizational systems and structures influence IMC implementation), and the other variations occur due to other factors as well as the random error. Thus, the Models' whole significance according to the results of ANOVA which show that the models are significant as $\mathrm{p}$ value is less than 0.05 . Thus, the results indicte how the change in the combination of predictor variables predict the level of change in the outcome variable. The result has shown that the External factors of IMC positively influence the Organizational system structure and the Benefits of IMC implementations positively influence the Organizational system structure. 
Table 5

Regression analysis results (Travel agencies)

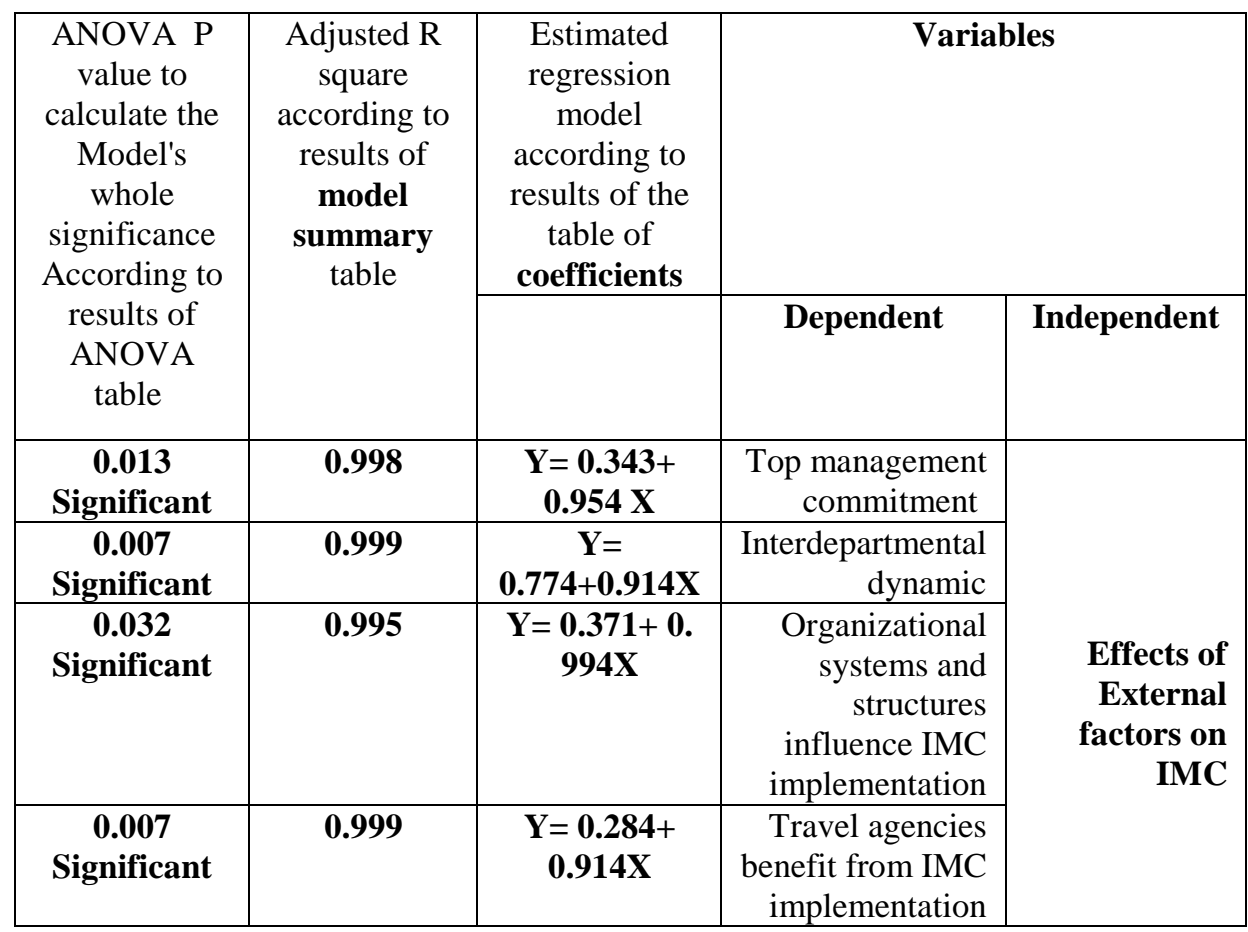

According to the results of multiple regression analysis for travel agencies shown in Table 5 the adjusted $\mathrm{R}$ square significant with the effects of external factors of travel agencies with all variables as the following:

- The independent variable (Effects of external factors of travel agencies on IMC) explains $99.9 \%$ of the variations in the dependent variable (Top management commitment).

- The independent variable (Effects of external factors of travel agencies on IMC) explains $99.9 \%$ of the variations in the dependent variable (Interdepartmental dynamic).And the other variations occur due to other factors as well as the random error.

- The independent variable (Effects of external factors of travel agencies on IMC) explains $99.5 \%$ of the variations in the dependent variable (Organizational systems and structures influence IMC implementation). And the other variations occur due to other factors as well as the random error.

- The independent variable (Effects of external factors of travel agencies on IMC) explains $99.9 \%$ of the variations in the dependent 


\section{Exploring The Importance Of Internal And External Factors Related To Integrated Marketing Communication In Five Star Hotels Travel Agencies}

variable (Travel agencies benefit from IMC implementation). And the other variations occur due to other factors as well as the random error.

- The Models' whole significance according to results of ANOVA shows that the models are significant as $\mathrm{p}$ values are less than 0.05

The pervious results indicating how changes in the combination of predictor variables predict the level of change in the outcome variable, and these resultsindicate that the External factors of IMC positively influence the Organizational system structure". However,there is no evidence on of the significance of the benefits from IMC implementation with in relation to any variable, which means that the travel agencies marketing managers don't believe in the relationship between the benefits of IMC and any of the internal and external factors.

In addition, Correlation is used to determine the relationship between a set of five variables. The value of correlation lies between $(-1$ to +1$)$, the Positive value shows that the relationship exists, andthe positive value shows stronger relationships between variables.

According to the results of hotels samples, the coefficient values in the previous table of correlation matrix indicate that the correlation coefficients for all variables are significant as p. value is less than 0.05 , and there are positive and strong correlations among all variables( between 0.998 and 1.000). This result therefore implies that the internal and external factors belonging to integrated marketing communication are playing a very important role when there ismacro environment stability and therefore a good benefit of implementing the integrated marketing communication will be available. Thus these results show that the External factors of IMC positively influence the internal factors of IMC, and Internal and external factors of IMC positively influence the Benefits of IMC implementation" 


\section{Table 6}

\section{Correlation matrix for hotels sample}

\begin{tabular}{|c|c|c|c|c|c|c|}
\hline & & $\begin{array}{c}\text { top } \\
\text { management } \\
\text { commitment }\end{array}$ & $\begin{array}{l}\text { interdepart } \\
\text { mental } \\
\text { dynamic }\end{array}$ & $\begin{array}{c}\text { organizati } \\
\text { onal } \\
\text { systems } \\
\text { and } \\
\text { structures } \\
\text { influence } \\
\text { IMC } \\
\text { implementa } \\
\text { tion } \\
\end{array}$ & $\begin{array}{c}\text { effects of } \\
\text { external } \\
\text { factors on } \\
\text { IMC }\end{array}$ & $\begin{array}{l}\text { Hotels and } \\
\text { travel } \\
\text { agencies } \\
\text { benefit from } \\
\text { IMC } \\
\text { implementat } \\
\text { ion }\end{array}$ \\
\hline \multirow{3}{*}{$\begin{array}{r}\text { Top } \\
\text { management } \\
\text { commitment }\end{array}$} & $\begin{array}{r}\text { Pearson } \\
\text { Correlatio } \\
n\end{array}$ & 1 & $.999 *$ & $.998 *$ & $.999 *$ & $.999 *$ \\
\hline & $\begin{array}{r}\text { Sig. }(2- \\
\text { tailed })\end{array}$ & & .026 & .045 & .026 & .026 \\
\hline & $\mathbf{N}$ & 77 & 77 & 77 & 77 & 77 \\
\hline \multirow{3}{*}{$\begin{array}{r}\text { Interdepartmen } \\
\text { tal dynamic }\end{array}$} & $\begin{array}{r}\text { Pearson } \\
\text { Correlatio } \\
n\end{array}$ & $.999 *$ & 1 & $1.000 *$ & $1.000 * *$ & $1.000 * *$ \\
\hline & $\begin{array}{l}\text { Sig. }(2- \\
\text { tailed })\end{array}$ & .026 & & .019 & .000 & .000 \\
\hline & $\mathbf{N}$ & 77 & 77 & 77 & 77 & 77 \\
\hline \multirow{3}{*}{$\begin{array}{r}\text { Organizational } \\
\text { systems and } \\
\text { structuresinflue } \\
\text { nce IMC } \\
\text { implementation }\end{array}$} & $\begin{array}{r}\text { Pearson } \\
\text { Correlatio } \\
n\end{array}$ & $.998 *$ & $1.000 *$ & 1 & $1.000 *$ & $1.000 *$ \\
\hline & $\begin{array}{l}\text { Sig. (2- } \\
\text { tailed) }\end{array}$ & .045 & .019 & & .019 & .019 \\
\hline & $\mathbf{N}$ & 77 & 77 & 77 & 77 & 77 \\
\hline \multirow{3}{*}{$\begin{array}{r}\text { Effects of } \\
\text { external factors } \\
\text { on IMC }\end{array}$} & $\begin{array}{r}\text { Pearson } \\
\text { Correlatio } \\
\mathrm{n}\end{array}$ & $.999 *$ & $1.000 * *$ & $1.000 *$ & 1 & $1.000 * *$ \\
\hline & $\begin{array}{l}\text { Sig. }(2- \\
\text { tailed })\end{array}$ & .026 & .000 & .019 & & .000 \\
\hline & $\mathbf{N}$ & 77 & 77 & 77 & 77 & 77 \\
\hline \multirow{3}{*}{$\begin{array}{r}\text { Hotels benefits } \\
\text { from IMC } \\
\text { implementation }\end{array}$} & $\begin{array}{r}\text { Pearson } \\
\text { Correlatio } \\
\mathrm{n}\end{array}$ & $.999 *$ & $1.000 * *$ & $1.000 *$ & $1.000 * *$ & 1 \\
\hline & $\begin{array}{l}\text { Sig. }(2- \\
\text { tailed })\end{array}$ & .026 & .000 & .019 & .000 & \\
\hline & $\mathbf{N}$ & 77 & 77 & 77 & 77 & 77 \\
\hline
\end{tabular}

*. Correlations significant at the 0.05 level (2-tailed).

**. Correlation is significant at the 0.01 level (2-tailed). 


\section{Exploring The Importance Of Internal And External Factors Related To Integrated Marketing Communication In Five Star Hotels Travel Agencies}

Table 7

\section{Correlation matrix for travel agencies sample}

\begin{tabular}{|c|c|c|c|c|c|c|}
\hline & & $\begin{array}{c}\text { top } \\
\text { management } \\
\text { commitment }\end{array}$ & $\begin{array}{c}\text { interdepar } \\
\text { tmental } \\
\text { dynamic }\end{array}$ & $\begin{array}{l}\text { organizational } \\
\text { systems and } \\
\text { structures } \\
\text { influence IMC } \\
\text { implementation }\end{array}$ & $\begin{array}{l}\text { effects of } \\
\text { external } \\
\text { factors on } \\
\text { IMC }\end{array}$ & $\begin{array}{c}\text { Hotels and } \\
\text { travel } \\
\text { agencies } \\
\text { benefits } \\
\text { from IMC } \\
\text { implementat } \\
\text { ion } \\
\end{array}$ \\
\hline \multirow{3}{*}{$\begin{array}{r}\text { Top } \\
\text { management } \\
\text { commitment }\end{array}$} & $\begin{array}{r}\text { Pearson } \\
\text { Correlation }\end{array}$ & 1 & $.999 *$ & $1.000 *$ & $1.000 *$ & $.999 *$ \\
\hline & $\begin{array}{l}\text { Sig. }(2- \\
\text { tailed) }\end{array}$ & & .020 & .019 & .013 & .020 \\
\hline & $\mathbf{N}$ & 70 & 70 & 70 & 70 & 70 \\
\hline \multirow{3}{*}{$\begin{array}{l}\text { Interdepartm } \\
\text { ental dynamic }\end{array}$} & $\begin{array}{r}\text { Pearson } \\
\text { Correlation }\end{array}$ & $.999 *$ & 1 & $.998 *$ & $1.000 * *$ & $1.000 * *$ \\
\hline & $\begin{array}{c}\text { Sig. }(2- \\
\text { tailed })\end{array}$ & .020 & & .039 & .007 & .000 \\
\hline & $\mathbf{N}$ & 70 & 70 & 70 & 70 & 70 \\
\hline \multirow{3}{*}{$\begin{array}{r}\text { Organization } \\
\text { al systems } \\
\text { and } \\
\text { structures } \\
\text { influence } \\
\text { IMC } \\
\text { implementati } \\
\text { on }\end{array}$} & $\begin{array}{r}\text { Pearson } \\
\text { Correlation }\end{array}$ & $1.000 *$ & $.998 *$ & 1 & $.999 *$ & $.998 *$ \\
\hline & $\begin{array}{l}\text { Sig. (2- } \\
\text { tailed) }\end{array}$ & .019 & .039 & & .032 & .039 \\
\hline & $\mathbf{N}$ & 70 & 70 & 70 & 70 & 70 \\
\hline \multirow{3}{*}{$\begin{array}{r}\text { Effects of } \\
\text { Macro } \\
\text { environment } \\
\text { on IMC }\end{array}$} & $\begin{array}{r}\text { Pearson } \\
\text { Correlation }\end{array}$ & $1.000 *$ & $1.000 * *$ & $.999 *$ & 1 & $1.000 * *$ \\
\hline & $\begin{array}{l}\text { Sig. }(2- \\
\text { tailed) }\end{array}$ & .013 & .007 & .032 & & .007 \\
\hline & $\mathbf{N}$ & 70 & 70 & 70 & 70 & 70 \\
\hline \multirow{3}{*}{$\begin{array}{r}\text { Hotels and } \\
\text { travel } \\
\text { agencies } \\
\text { benefits from } \\
\text { IMC } \\
\text { implementati } \\
\text { on }\end{array}$} & $\begin{array}{r}\text { Pearson } \\
\text { Correlation }\end{array}$ & $.999 *$ & $1.000 * *$ & $.998 *$ & $1.000 * *$ & 1 \\
\hline & $\begin{array}{l}\text { Sig. (2- } \\
\text { tailed) }\end{array}$ & .020 & .000 & .039 & .007 & \\
\hline & $\mathbf{N}$ & 70 & 70 & 70 & 70 & 70 \\
\hline
\end{tabular}

*. Correlations significant at the 0.05 level (2-tailed).

**. Correlation is significant at the 0.01 level (2-tailed).

According to the results of Correlation matrix for travel agencies sample, the correlation coefficients for all variables are significant as $\mathbf{p}$. value is less than 0.05 , and there is a positive and strong correlation among all 
variables (between 0.998 and 1.000). Thus these results indicated that the External factors of IMC positively influence the internal factors of IMC, and

the Internal and external factors of IMC positively influence the Benefits of IMC implementation"

To know the differences between Hotel marketing managers and travel agencies marketing managers'opinions about the importance of internal and external factors of IMC implementation the authors put the samples in T test as shown in table 8

\section{Table 8}

Independent Samples T-Test

\begin{tabular}{|c|c|c|c|c|c|c|}
\hline \multicolumn{7}{|c|}{ t-test for Equality of Means } \\
\hline \multirow[b]{2}{*}{ t } & \multirow[b]{2}{*}{ df } & \multirow[b]{2}{*}{ Sig. (2-tailed) } & \multirow{2}{*}{$\begin{array}{c}\text { Mean } \\
\text { Difference }\end{array}$} & \multirow{2}{*}{$\begin{array}{l}\text { Std. Error } \\
\text { Difference }\end{array}$} & \multicolumn{2}{|c|}{$\begin{array}{l}95 \% \text { Confidence Interval of the } \\
\text { Difference }\end{array}$} \\
\hline & & & & & Lower & Upper \\
\hline .236 & 40 & .815 & .02619 & .11101 & $-19817-$ & .25055 \\
\hline .236 & 39.595 & .815 & .02619 & .11101 & -19824- & .25062 \\
\hline
\end{tabular}

According to the results of $\mathrm{T}$ testtheP value for hotels sample and travel agencies sample is more than $0.05(0.815)$ so the differences between the two samples' means is not significant", and that means that there is no difference among the responses of respondents of the hotels' sample and travel agencies sample regarding all items. Thus, it can be assumed that the hotels marketing managers and travel agencies managers have a moderating effect on the indirect link between the variables "integration of marketing communication" effect among the two groups.

\section{Discussion and Conclusion}

This study proposes to capture the current and future scope of IMC in five star hotels and travel agencies as the paper highlights a set of internal factors, including aspects related to top management, market orientation, brand orientation, organization structure, decision-making model and crossfunctional management. In addition, the organization size and its typology represent other internal factors. Secondly, some external influences are highlighted, such as technological and competitive turbulence and the cultural and institutional environment, political in which the company is operating. Finally, the paper sheds light on the main consequences and 


\section{Exploring The Importance Of Internal And External Factors Related To Integrated Marketing Communication In Five Star Hotels Travel Agencies}

benefits of IMC in terms of financial, brand and marketing communication outcomes, and effects on stakeholder and agency-client business

relationships. This purpose concord with Pickton 2001 who states that IMC isa process which involves the management and organization of all 'agents' in the analysis, planning, implementation and control of all marketing communication contacts, media, messages and promotional tools focused on selected target audiences in such a way as to derive the greatest economy, efficiency, effectiveness, enhancement and coherence of marketing communications effort in achieving predetermined product and corporate marketing communications objectives.

The review allows authors to formulate the research hypotheses and to model the driving-factors and effects of IMC.

The paper highlights a set of internal factors, including aspects related to top management, market orientation, brand orientation, organization structure, decision-making model and cross-functional management. In addition, the size of the organization and its typology represent other internal antecedents. Secondly, some external influences are highlighted, such as technological and competitive turbulence and the cultural and institutional environment in which the company is operating. Finally, the paper sheds light on the main consequences and benefits of IMC in terms of customer attitudes,customer loyalty, customer retention, financial outcomes, and effects on hotels and travel agencies

According to the findings of the study, the results reveal that the Hotels have more management commitment towards IMC than the travel agencies companies did, and implementation of IMC was more affected by the stability of the macro-environment than the travel agencies companies. Also the hotels had a better understanding of IMC and its benefits more than the travel agencies. However the travel agencies showed a greater influence of implementation of market orientation, brand orientation in the levels of IMC adopted, and Professional training and expertise in cross-functional management related to interdepartmental dynamic (Hotels: M 3.6; SD 0.431/ Travel Agencies: M 4.02; SD 0.128) and organizational systems and structures (Hotels: M 3.88; SD 0.207/ Travel Agencies: M 3.90; SD 0.097). The items under these variables represent a negative attitude towards integrated marketing communication and those two factors in hotels that are likely to be less influential in the degree of integration. On the contrary, the achievement of the desired degree of integration would produce a number of effects on the effectiveness of marketing communication efforts, on brand responsibility, marketing communication, Qualification/training, experience 
and abilities. In addition, the lack of horizontal communication was expected to be low in the organizations that do not encourage the concept of integrated marketing communication.

A close look at both Tables 1 and 2 points out some differences in items (Table 2) as well as variables (Table 3) which helpshave a clear comparison between hotels and travel agencies. This comparison of variables can be seen in Table 3. On a five-point Likert scale where $1=$ strongly disagree and $5=$ strongly agree, values above the midpoint of three show agreement. To find the differences in hotels and travel agencies, the largest gap generating items and variables can be interpreted.

The largest gap occurrs in the organizational systems and structures, 0.02 , indicating that marketing managers in travel agencies have strong brand responsibility and marketing communication towards the IMC. This gap qualifies IMC in travel agencies as a method to control messages the customers and stakeholders use to form a unique and good image about the organization. On the other hand, this control of messages in hotels may lead to frustration when guests require responses for their special needs or in extraordinary circumstances. On the other hand, the lowest gap score calculated belongs to the Hotels and travel agencies benefits from IMC implementation variable with 0.19 . This finding indicates that marketing managers in both locations have similar focus and commitment to all aspects that most influence the management of IMC as a business process. Top management commitment implies that senior managers ensure coherence between what they say and what they do in order to prevent middle managers from perceiving ambiguity that can damage the desired integration.

As for the remaining variables - top management commitment, effects of external factors on IMC, Hotels and travel agencies benefit from IMC implementation. Results reveal that sales managers in hotels are more aware of the significance of these issues in implementing the integrated marketing communication than the sales managers in the travel agencies.

According to the results of the adjusted $\mathrm{R}$ square for the sample of hotels it is found that:

1- The independent variable (Effects of external factors of hotels on IMC) has a strong significant relationship with (Organizational systems and structures influence IMC implementation).

2- The independent variable (Hotels benefit from IMC implementation) has a significant strong relationship with (Organizational systems and structures influence IMC implementation). 


\section{Exploring The Importance Of Internal And External Factors Related To Integrated Marketing Communication In Five Star Hotels Travel Agencies}

According to the results of the adjusted $\mathrm{R}$ square for travel agencies sample, it is found that:

1- The independent variable (Effects of external factors of travel agencies on IMC) has a significant relationship with (Top management commitment, Interdepartmental dynamic, Organizational systems and structures influence IMC implementation. However, the results indicating that there's no evidence on the significance of the benefits from IMC implementation with any variable which means that the travel agencies marketing managers do not believe in the relationship between the benefits of IMC and any of the internal and external factors.

Furthermore, findings reveal that the correlation coefficients for all variables in both of hotels and travel agencies are significant as p. value is less than 0.05 , and there are positive and strong correlations among all variables(between 0.998 and 1.000). This result therefore implies that the internal and external factors belonging to integrated marketing communication play a very important role when there ismacro environment stability and therefore a good benefit of implementing the integrated marketing communication will be available.

Additionally, the results of $\mathrm{T}$ test reveal that P.Value for hotels sample and travel agencies sample is more than $0.05(0.815)$.So, we accept the null hypothesis "the differences between the two samples' means is not significant", and that means there is no difference among the responses of respondents of hotels sample and travel agencies regarding all items.

\section{LIMITATIONS AND IMPLICATIONS FOR FURTHER RESEARCH}

Findings of this research should be interpreted in light of the following limitations: First, this research uses a convenience sampling technique to select its respondents. Consideration must be taken when generalizing the results of this study to other countries or regions. Furthermore, the research is confined to five-star hotels and travel agencies category "A" in Cairo and Alexandria. Future studies may consider including other regions or provinces to increase the scope of the findings of the research. Also more efficient and effective marketing communication strategy, which takes the dynamics of the customer relationship lifecycle, should be considered. 


\section{REFERENCES}

Ambler, T and Barrow, S. 1996 .The Employer Brand, Journal of Brand Management, 4 (3) , pp. 185-206.

Beard, F.1996. Integrated Marketing Communications: New Role Expectations And Performance Issues In The Client-Ad Agency Relationship?”,Journal Of Business Research, 37(3), pp. 207-215.

Cornelissen, J. P., Lock, R. A and Gardner, H.2001. The Organization Of External Communication Disciplines: An Integrative Framework Of Dimensions and Determinants, International Journal Of Advertising, 20 (1), pp. 67-88.

Duncan, T and Everett, S. E. 1993. Client Perceptions Of Integrated Marketing Communications, Journal Of Advertising Research, 32 (3) ,pp. 33-39.

Duncan, T. and Moriarty, S.E. 1997. Driving Brand Value: Using Integrated Marketing to Manage Profitable Stakeholder Relationships. New York: McGraw-Hill

Duncan,T. 2002 .IMC Using Advertising and Promotion to Build Brands , New York: McGraw Hill,pp.15,20

Einwiller, S.and Boenigk, M. 2011 Examining the Link Between Integrated Communication Management And Communication Effectiveness In Medium-Sized Enterprises. Journal Of Marketing Communications, 17, pp.1-17

Ejebro.K.2007 .Integrated Marketing Communication Connecting Company And Customer .Un Published Master's Thesis .Lulea University Of Technology .Department Of Computer Science and Electronic Engineering .pp.6

Ekhlassi,A, Maghsoodi,V and Mehrmanesh, S .2012. Determining the Integrated Marketing Communication Tools for Different Stages of Customer Relationship in Digital Era. International Journal of Information and Electronics Engineering. 2(5), pp.761-765.

Gato ,R..2011.Redefining The Agency Model: The Benefits Of An IMC Approach.Unpublished Master Thesis. Rowan University.pp.14

Ghodeswar,M,B .2008 Building Brand Identity In Competitive Markets: A Conceptual Model. Journal of Product \& Brand Management.17 (1),pp.4-12

Grewal,D. and Levy,M.2011.Marketing .3rded.New York : McGraw-Hill

Holm, O. 1998. Aspects of Marketing Communication and Operational Concepts in Companies and Organizations, No. 73, Swedish School of Economics and Business Administration, Helsinki

Holm, O. 2006. Integrated marketing communication from tactics to strategy. Corporate communication.An International Journal. 11 (1) ,pp.23 - 33

Hudson, S. and Hudson, L. 2010.The Marketing of Golf Tourism. Marketing Communications. Oxford: Goodfellow Publisher. pp.134

Johnson, G. and Scholes, K. 2002.Exploring Corporate Strategy. Edinburgh:Prentice-Hall, 


\section{Exploring The Importance Of Internal And External Factors Related To Integrated Marketing Communication In Five Star Hotels Travel Agencies}

Joseph .E. P, Thomas, E.Hand Edward, J.1996 . Exploring decision-making approaches and responsibility for developing marketing communications strategy, Journal of Business research. 37(3) pp. 217-223.

Judd, C.M., Smith, E.R. and Kidder, L.H. 1991.Research Methods in Social Research, 6th ed.. New York.: Harcourt Brace Jovanovich College Publishers.

Kerr, G. F and Patti,C,H. 2002 .Integrated Marketing Communications (IMC): Where to from here? Queensland University of Technology .Anzma conference Processing .pp.2381-2387[Online] Available at:http://www.anzmac.org/conference_archive/2002/papers/pdfs/p296_kerr. pdf [Accessed :25 March 2007]

Kim, I., Han, D. and Schultz, D.E. 2004. Understanding the Diffusion of Integrated Marketing Communication, Journal of Advertising Research. 44( 1) pp. 3145.

Kitchen, P. J. 2010.Integrated Brand Marketing and Measuring Returns. Basingstoke: Palgrave-Macmillan .

Kotler, P. 2003.Marketing Management.11th ed.,Englewood Cliff,NJ:Prentice-Hall

Kotler,P.,Armstrong, G., Saunders,J., andWong,V. 1999.Principles of Marketing, 2nded.Harlow: Prentice-Hall.

Lee,S,L. 2004 .The Benefits Of Integrated Marketing Communication In MultiLevel Marketing-A Case Study Of Amway Taiwan Limited Company. University Of East Angela School Of Management .pp.161-189 [online] available at: http://www.cadsm.org/dsrctn/research/Chinese/papers2209/2004-Shanghai-02-tradition.pdf [Accessed 26 December 2014]

Levene, H. (1960). Robust tests for equality of variances.

Contributions to Probability and Statistics. Palo Alto, California: Stanford University Press, pp. 278-292.

Low, G. 2000. Correlates of Integrated Marketing Communications. Journal of Advertising Research. 40(3),pp. 27-39

Lucia ,P.,Salvador Del B.G. , Philip J. Kitchen .2012. How Integrated Marketing Communications (IMC)Works? A Theoretical Review And An Analysis Of Its Main Drivers And Effects, Journal Of Communication Y Sociedad .25 (1),pp.313-348

Pettegrew,S.L. 2001. Barriers To IMC Adaptation in Corporate America. Journal of Integrated Communication av.29-37 available at :http://jimc.medill.northwestern.edu/wp

content/uploads/sites/9/2014/02/archives/2001/loyd.pdf [access 13-12-2014]

Phelps, J. E., Harris, T. E. and Johnson, E. 1996. Exploring decision-making approaches and responsibility for developing marketing communications strategy.Journal of Business Research. 37(3) pp. 217-223

Pickton, D. and Broderick, A. 2001.Integrated Marketing Communications, Harlow :Pearson Education Limited. 
Rehman,S.U. and Ibrahim,S,M. 2011. Integrated Marketing Communication and Promotion, Journal of Arts, Science \&Commerce .2(4), pp.187-191

Reid, M. 2005 Performance Auditing Of Integrated Communication (IMC) Actions and Outcomes. Journal Of Advertising, 34( 4) pp. 41-54.

Rust, T.R.,Amber,T. Carpenter,S.G.Kumar,V and Srivastava,K.R. 2004.Measuring Marketing Productivity: Current Knowledge and Future Directions.Journal of Marketing, 68, pp. 76.89.

Saeed,R., Naeem, B. Bilal, M. and Naz,U. 2013. Integrated Marketing Communication: A Review Paper, Interdisciplinary. Journal Of Contemporary Research In Business. 5 ( 5) ,pp.124-133

Schults,D.E.,Tannenbalim,S.I and Lauternborn.R.F.1992.Integrated Marketing Communications :Pulling it together and Making it work.Chicago. Il: NTC Business Books.

Schultz, D. E. 1996. The Inevitability of Integrated Communications. Journal of Business Research. 37(3), pp. 139-146.

Schultz, D. E. and Kitchen, P. J. 1997 Integrated marketing communications in U.S. advertising agencies: An exploratory Study.Journal of Advertising Research. 37( 5), pp. 7-18.

Schultz, D. E.and Kitchen, P. J. 2000 Communicating Globally. An Integrated Marketing Approach,Lincolnwood:NTC Business Books, PP. 35-67

Schultz, D. Tannenbaum, S. and Lauterborn, R.1993. Integrated Marketing Communications, Chicago:Ilinois, NTC Business Books,

Schultz, D.E. and Schultz, H.F. 2004.IMC Next Generation . NY: McGraw-Hill.

Schultz, D.E. and Kitchen,P.J. 1997. Integrated Marketing Communications In U.S. Advertising Agencies: An Exploratory Study. Journal of Advertising Research. 37(5),PP.7-18

Shimp, T. A. 2010. Advertising, Promotion and other aspects of Integrated Marketing Communications.8thed.Mason, Wadsworth,CA: Cengage Learning.PP.10

Smith, P. 1996.Benefits and Barriers to Integrated Communications. Admap, February .

Smith, P.R.. Berry, C. and Pulford, A. 1999.Strategic Marketing Communications. London: Kogan Page

Sotiriadis, M., and van Zyl, C. 2013. Electronic word-of-mouth and online reviews in tourism services: the use of twitter by tourists. Electronic Commerce Research, 13(1)pp. 103-124

Swain, W. N. 2004. Perceptions of IMC after a Decade of Development: Who's at the Wheel, and how can We Measure Success? Journal of Advertising Research .44 (1),PP.46-65

Wang, Y.J., Wu, C. and Yuan, J. 2009. The role of Integrated Marketing Communications (IMC) on heritage destination visitations. Journal of Quality Assurance in Hospitality \& Tourism,10(3), pp. 218-231 